University of Montana

ScholarWorks at University of Montana

\title{
$5-2011$
}

\section{Thinking Outside the Channel: Modeling Nitrogen Cycling in Networked River Ecosystems}

\author{
Ashley M. Helton \\ Geoffrey C. Poole \\ Judy L. Meyer \\ Wilfred M. Wollheim \\ Bruce J. Peterson \\ See next page for additional authors
}

Follow this and additional works at: https://scholarworks.umt.edu/biosci_pubs

Part of the Biology Commons

Let us know how access to this document benefits you.

\section{Recommended Citation}

Helton, Ashley M.; Poole, Geoffrey C.; Meyer, Judy L.; Wollheim, Wilfred M.; Peterson, Bruce J.; Mulholland, Patrick J.; Bernhardt, Emily S.; Stanford, Jack Arthur; Arango, Clay; Ashkenas, Linda R.; Cooper, Lee W.; Dodds, Walter K.; Gregory, Stanley V.; Hall, Robert O. Jr.; Hamilton, Stephen K.; Johnson, Sherri L.; McDowell, William H.; Potter, Jody D.; Tank, Jennifer L.; Thomas, Suzanne M.; Valett, H. Maurice; Webster, Jackson R.; and Zeglin, Lydia, "Thinking Outside the Channel: Modeling Nitrogen Cycling in Networked River Ecosystems" (2011). Biological Sciences Faculty Publications. 232.

https://scholarworks.umt.edu/biosci_pubs/232

This Article is brought to you for free and open access by the Biological Sciences at ScholarWorks at University of Montana. It has been accepted for inclusion in Biological Sciences Faculty Publications by an authorized administrator of ScholarWorks at University of Montana. For more information, please contact scholarworks@mso.umt.edu. 


\section{Authors}

Ashley M. Helton, Geoffrey C. Poole, Judy L. Meyer, Wilfred M. Wollheim, Bruce J. Peterson, Patrick J. Mulholland, Emily S. Bernhardt, Jack Arthur Stanford, Clay Arango, Linda R. Ashkenas, Lee W. Cooper, Walter K. Dodds, Stanley V. Gregory, Robert O. Hall Jr., Stephen K. Hamilton, Sherri L. Johnson, William H. McDowell, Jody D. Potter, Jennifer L. Tank, Suzanne M. Thomas, H. Maurice Valett, Jackson R. Webster, and Lydia Zeglin 


\section{Thinking outside the channel: modeling nitrogen cycling in networked river ecosystems}

Ashley M Helton ${ }^{1 *}$, Geoffrey C Poole ${ }^{1,2}$, Judy L Meyer ${ }^{1}$, Wilfred M Wollheim ${ }^{3}$, Bruce J Peterson ${ }^{4}$, Patrick J Mulholland ${ }^{5}$, Emily S Bernhardt ${ }^{6}$, Jack A Stanford ${ }^{7}$, Clay Arango ${ }^{8}$, Linda R Ashkenas, Lee W Cooper ${ }^{10}$, Walter K Dodds ${ }^{11}$, Stanley V Gregory ${ }^{9}$, Robert O Hall Jr ${ }^{12}$, Stephen K Hamilton ${ }^{13}$, Sherri L Johnson ${ }^{14}$, William H McDowell ${ }^{15}$, Jody D Potter ${ }^{15}$, Jennifer L Tank ${ }^{8}$, Suzanne M Thomas ${ }^{4}$, H Maurice Valett ${ }^{16}$, Jackson R Webster ${ }^{16}$, and Lydia Zeglin ${ }^{17}$

Agricultural and urban development alters nitrogen and other biogeochemical cycles in rivers worldwide. Because such biogeochemical processes cannot be measured empirically across whole river networks, simulation models are critical tools for understanding river-network biogeochemistry. However, limitations inherent in current models restrict our ability to simulate biogeochemical dynamics among diverse river networks. We illustrate these limitations using a river-network model to scale up in situ measures of nitrogen cycling in eight catchments spanning various geophysical and land-use conditions. Our model results provide evidence that catchment characteristics typically excluded from models may control river-network biogeochemistry. Based on our findings, we identify important components of a revised strategy for simulating biogeochemical dynamics in river networks, including approaches to modeling terrestrial-aquatic linkages, hydrologic exchanges between the channel, floodplain/riparian complex, and subsurface waters, and interactions between coupled biogeochemical cycles.

Front Ecol Environ 2011; 9(4): 229-238, doi:10.1890/080211 (published online 8 Sep 2010)

$\mathrm{R}^{\mathrm{n}}$ ivers receive, transport, and process nutrients, contaminants, and other natural and human-derived materials from the landscape and deliver these constituents to downstream waters. Because river networks link terrestrial landscapes to lakes and oceans, perturbations to river ecosystems can influence biogeochemical cycling at local, regional, and global scales. Select human activities, such as fertilizing agricultural lands and burning fossil fuels, have delivered excess nitrogen to rivers, thereby increasing nitrogen export to coastal areas and exacerbating

\section{In a nutshell:}

- Understanding the responses of riverine nitrogen dynamics to anthropogenic perturbations is important for forecasting changes in the global nitrogen cycle

- Key research includes developing more realistic models of river-network hydrogeomorphology and biogeochemistry applicable across different catchments

- Models that can represent a breadth of biogeochemical processes within, and hydrologic connections between, the channel, floodplain/riparian complex, and subsurface waters will advance understanding of river nitrogen cycling

${ }^{1}$ Odum School of Ecology, University of Georgia, Athens, GA *(amhelton@uga.edu); ${ }^{2}$ Department of Land Resources and Environmental Sciences, Montana State University, Bozeman, MT; ${ }^{3}$ Complex Systems Research Center, University of New Hampshire, Durham, NH (continued on p238) hypoxic zones in nearshore seas worldwide (Diaz and Rosenberg 2008). However, as nitrogen is transported downstream, some may be lost to the atmosphere via denitrification, the microbially mediated reduction of nitrate $\left(\mathrm{NO}_{3}^{-}\right)$to nitrogen gas. Mass-balance accounting across broad regions suggests that denitrification losses substantially reduce riverine nitrogen loads to the ocean (Seitzinger et al. 2006).

Recent research has focused on modeling nitrogen dynamics in river networks, partly because biogeochemical processes cannot be measured contiguously across river networks. Initial applications of riverine nitrogen models focused on predicting nitrogen export from large watersheds (reviewed by Alexander et al. 2002). Additional applications have included efforts to model biogeochemical processes that reduce downstream nitrogen transport, such as denitrification (Alexander et al. 2000; Seitzinger et al. 2002; Darracq and Destouni 2005; Mulholland et al. 2008; Alexander et al. 2009). Unfortunately, difficulty in accounting for spatial and temporal variations in the biogeochemical controls of denitrification (Boyer et al. 2006) has created major uncertainties in simulation results, which hamper forecasting of river-network biogeochemistry under future scenarios of climate disruptions, urbanization, and human population growth.

Here, we evaluate common modeling approaches and assumptions about river and catchment hydrogeomorphology and biogeochemistry, by scaling in situ denitrifica- 
Table 1. Descriptions of study catchments

\begin{tabular}{|c|c|c|c|c|}
\hline Site location & Biome & $\begin{array}{c}\text { Basin area } \\
\left(\mathrm{km}^{2}\right)\end{array}$ & $\begin{array}{c}\% \\
\text { agriculture }\end{array}$ & $\begin{array}{c}\% \\
\text { urban }\end{array}$ \\
\hline $\begin{array}{l}\text { Little Tennessee River, } \\
\text { North Carolina (NC) }\end{array}$ & $\begin{array}{l}\text { Warm temperate } \\
\text { deciduous forest }\end{array}$ & 361 & 10 & 7 \\
\hline Mill Creek, Kansas (KS) & Grassland & 1008 & 16 & 3 \\
\hline Tualatin River, Oregon (OR) & Humid coniferous forest & 1828 & 27 & 21 \\
\hline Flat Creek, Wyoming (WY) & Semiarid coniferous forest & 400 & 0.4 & 2 \\
\hline $\begin{array}{l}\text { Ipswich River, } \\
\text { Massachusetts (MA) }\end{array}$ & $\begin{array}{l}\text { Cool temperate } \\
\text { deciduous forest }\end{array}$ & 381 & 6 & 31 \\
\hline $\begin{array}{l}\text { Little Rabbit River, } \\
\text { Michigan (MI) }\end{array}$ & $\begin{array}{l}\text { Cool temperate } \\
\text { deciduous forest }\end{array}$ & 126 & 72 & 9 \\
\hline $\begin{array}{l}\text { Río Piedras, } \\
\text { Puerto Rico (PR) }\end{array}$ & $\begin{array}{l}\text { Moist evergreen } \\
\text { tropical forest }\end{array}$ & 40 & 27 & 42 \\
\hline $\begin{array}{l}\text { Rio Grande, } \\
\text { New Mexico (NM) }\end{array}$ & Arid grassland & 40780 & 0.7 & 1 \\
\hline
\end{tabular}

network models to represent downstream changes in channel morphology, hydrology, and biogeochemistry (WebPanel 1), as well as a recently documented reduction in streambed denitrification efficiency with increasing $\mathrm{NO}_{3}^{-}$concentration (Mulholland et al. 2008).

We treated the model and its assumptions as a hypothesis describing downstream transport and denitrification of $\mathrm{NO}_{3}^{-}$in river networks and explicitly tested this hypothesis by evaluating model performance in eight small river networks (Table 1). We conducted sampling of $\mathrm{NO}_{3}{ }^{-}$concentrations (the model response variable), channel width, and discharge at locations across each network (Figure 2) during low-flow conditions for 2 years. Observed patterns of tion measurements from headwater streams (Mulholland et al. 2008) to river networks in eight different catchments (Table 1). Using the model results, we identify additional dynamics and catchment characteristics that are important for understanding biogeochemical cycling, illustrate strategies for improving simulation of river biogeochemistry, and prioritize steps for future model development.

\section{A river-network modeling experiment}

We conducted simulation experiments using a model of river-network $\mathrm{NO}_{3}{ }^{-}$dynamics described by Mulholland et al. (2008) to systematically evaluate assumptions about river and catchment hydrogeomorphology and biogeochemistry (WebPanel 1; Figure 1). The model incorporates equations and assumptions commonly used in river-

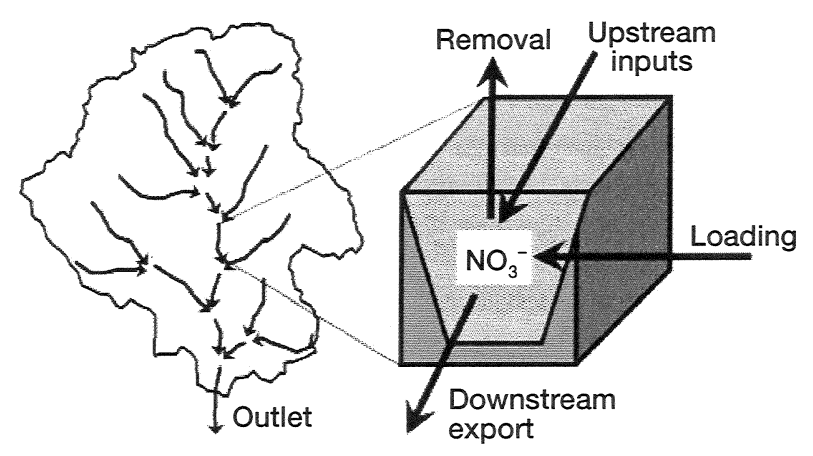

Figure 1. River-network model structure. Following the methods presented by Mulholland et al. (2008), river networks were divided into segments, defined as the length of stream between tributary junctions. Water and $\mathrm{NO}_{3}^{-}$flux into (upstream inputs and loading from the terrestrial landscape) and out of (downstream export and removal via denitrification) each segment were modeled. Fluxes are described in WebPanel 1. downstream changes in width and discharge, combined with network topology from 1:24000 US Geological Survey (USGS) maps, served to parameterize network morphology and hydrology. We determined model parameters for denitrification from in situ measurements of whole stream-reach denitrification replicated across nine headwater (1st- to 3rd-order) streams in or near each catchment (Mulholland et al. 2008; WebTable 1).

We used inverse modeling to estimate the spatial pattern of $\mathrm{NO}_{3}^{-}$loading rates to streams by applying a model-independent parameter optimizer (Parameter ESTimation, version 10.1, SS Papadopoulos and Associates Inc). We estimated $\mathrm{NO}_{3}{ }^{-}$loading rates necessary for the model to exactly reproduce observed patterns of $\mathrm{NO}_{3}{ }^{-}$concentrations across each network. This approach allowed us to calculate spatial variation in $\mathrm{NO}_{3}{ }^{-}$ loading rates across each catchment (Figure 2), assuming that our hypothesized representation of nitrogen cycling (WebPanel 1) was correct. Thus we were able to falsify our hypothesis (ie reject the model) anywhere that estimated loading patterns were clearly unrealistic. To hedge against rejecting a reasonable representation of river-network biogeochemistry (eg rejecting the model because of the possibility of sampling error or localized dynamics atypical of conditions across the larger catchment), we rejected the model only when $>10 \%$ of loading estimates for a catchment fell outside of a realistic range (0-6.96 $\mathrm{kg} \mathrm{km}^{-2} \mathrm{~d}^{-1}$, the highest loading estimate from a literature review of 140 catchments; WebTable 2).

On the basis of these criteria, we accepted the model in only two of the eight catchments: the Little Tennessee River, North Carolina, and Mill Creek, Kansas (Figure 2). Thus, we con- 
clude that aspects of these two river networks are largely consistent with model assumptions, including: (1) catchment topography drives water and $\mathrm{NO}_{3}{ }^{-}$accumulation; (2) channel width increases in proportion to discharge; (3) streambed denitrification is the primary mechanism of nitrogen removal; and (4) $\mathrm{NO}_{3}{ }^{-}$concentration is the primary determinant of streambed denitrification rate.

In the remaining six catchments, we used model results, catchment characteristics, and findings from published research to identify deviations between model assumptions and catchment dynamics as potential sources of model failure. This information highlights important shortcomings in existing approaches to simulating river-network biogeochemistry and provides a basis for prioritizing needs for future model improvements.

\section{Model assumptions versus catchment conditions}

Our assessment suggests that model errors likely result from important deviations between catchment conditions and commonly applied model assumptions, including assumptions that: (1) oversimplify catchment hydrology; (2) oversimplify river-network hydrogeomorphology;

(3) incorporate unidirectional uptake of nitrogen rather than cycling in the context of other elements (ie stoichiometric constraints); and (4) focus on base-flow or annual mean conditions, ignoring the ecological relevance of seasonal cycles and temporal dynamics.

\section{Catchment hydrology and nitrogen delivery to streams}

Five of the modeled catchments provide examples of the influence of catchment hydrology on river-network biogeochemistry. In the Tualatin River, Oregon (13\% unrealistic loading rates; Figure 2), two wastewater treatment facilities discharge 60 million gallons (over 227 million L) per day of treated wastewater into the river (Clean Water Services unpublished data), and agricultural water withdrawals occur throughout the network (Oregon Water Resources Department, www.wrd.state.or.us). When we reparameterized our model to incorporate the spatial arrangement of nitrogen and water delivery from these point-source inputs, unrealistic loading estimates were nearly eliminated from the model results (reduced from $13 \%$ to $3 \%$ ).

The Río Piedras, Puerto Rico; Little Rabbit River, Michigan; and Flat Creek, Wyoming catchments had high percentages of unrealistic loading rates (23\%, 27\%, and 24\%, respectively; Figure 2). Most land in the Little Rabbit River catchment is agricultural (72\% of catchment area; Table 1), with numerous high-density animal operations (USDA 2002) and extensive tile drainage systems (eg Figure 3a). The Río Piedras catchment has $42 \%$ urban land cover (Table 1) and contains many straightpipe sewage lines from residential buildings to streams (eg Figure 3b). Water withdrawals from Flat Creek reduce flow substantially (eg to dryness; Figure 3c) in its headwaters, before water is added downstream by both a diversion from Gros Ventre River and spring flows. In these three catchments, anthropogenic delivery systems (eg tile drains, sewers, irrigation systems), rather than catchment topography, dominate patterns of water and nitrogen delivery to streams, thus violating important model assumptions (WebPanel 1).

The case of the Rio Grande, New Mexico, is even more extreme. Patterns of base flow in the system are so completely dominated by dams, headgates (eg Figure 3d), and other flow regulation structures that no semblance of a convergent flow network remains along the river corridor. The hydrology of the river deviates so far from the underlying hydrologic basis of our model (ie topographi- 

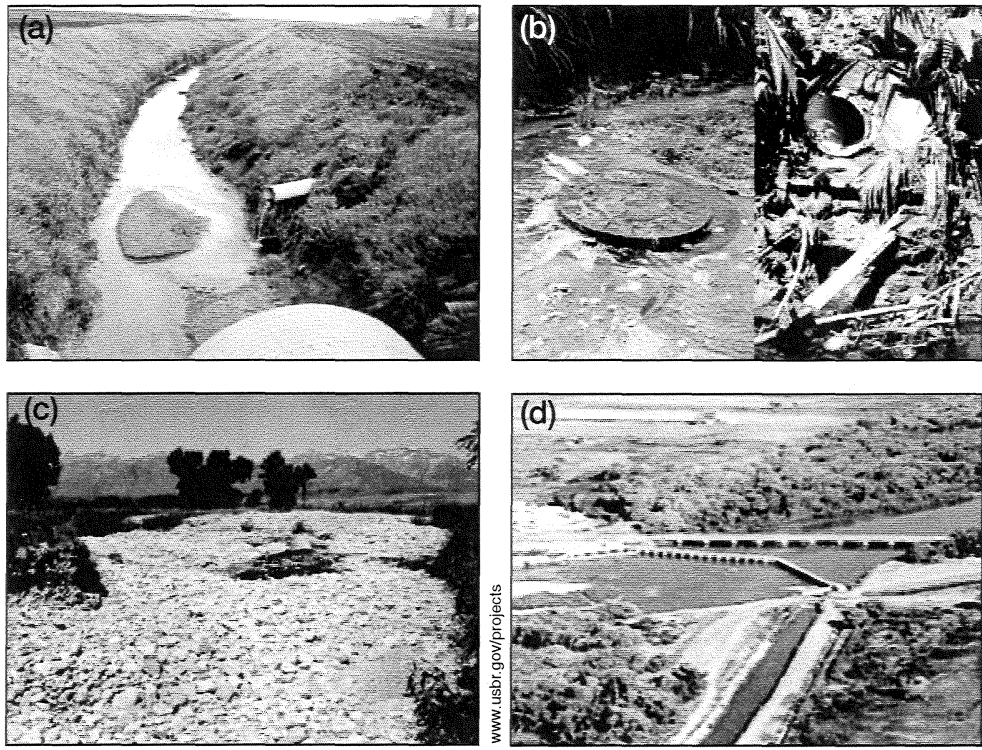

Figure 3. Examples of anthropogenic alterations to hydrology and nitrogen delivery that deviate from assumptions within modeled catchments. (a) Agricultural tile drains, Rabbit River, MI, catchment. (b) Sanitary sewer overflow (left) and straight-pipe sewer discharge (right), Río Piedras, PR, catchment. (c) Alluvial stream reach irrigated to dryness, Flat Creek, WY, catchment; (d) Water abstraction, Isleta diversion, Rio Grande, NM.

cally driven flow accumulation) that we were unable to apply our model to the system (Figure 2).

These five catchments illustrate the importance of incorporating the spatial patterns of water and nitrogen delivery to river networks into models. Indeed, previous modeling work has shown that accounting for the spatial arrangement of nitrogen inputs to rivers can improve model estimates of nitrogen export (Alexander et al. 2002), and spatial and temporal heterogeneity in water and nitrogen delivery increases uncertainty in modeled nitrogen export (Lindgren and Destouni 2004). Despite the need to incorporate spatiotemporal patterns of nitrogen delivery, many river-network models rely on a massbalance or a statistical approach to estimate nitrogen sources, resulting in steady-state mean annual estimates of nitrogen delivery to rivers. Such model applications are useful and appropriate for scaling up annual catchment nitrogen exports, based on data from distributed monitoring stations. However, more realistic representations of spatiotemporal variation in water and nitrogen delivery will be necessary for imperatives such as forecasting river biogeochemical responses to continued human population growth coupled with climate change.

\section{River hydrogeomorphology}

Both the Ipswich River, Massachusetts, and Flat Creek, Wyoming, catchments provide intriguing examples of hydrogeomorphic controls on river-network biogeochemistry. The Ipswich River has extensive water withdrawals for urban use in its headwaters (Zarriello and Ries 2000) and it flows through numerous wetland complexes, which comprise $20 \%$ of catchment land cover (eg Figure 4a). The Flat Creek network, in addition to hydrologic alteration (described above), has a large wetland $\left(\sim 2.3 \mathrm{~km}^{2}\right)$ along the main stem of Flat Creek, and high rates of exchange between the channel and an extensive hyporheic zone (the area directly beneath the channel and floodplain where surface and subsurface waters are freely exchanged) typical of western US alluvial streams (eg Figure $4 b$ ). In both catchments, our analysis yielded large percentages of negative loading estimates (Figure 2), indicating that our model underpredicts nitrogen removal in many reaches of each network.

Incorporating headwater withdrawals from the Ipswich River into the model did not reduce the percentage of unrealistic loading estimates. However, loading estimates were negatively correlated with the fraction of stream length intersecting wetlands (WebFigure 1), suggesting that wetlands are an important nitrogen sink not represented by the model. In Flat Creek, biotic removal of $\mathrm{NO}_{3}^{-}$in the hyporheic zone (sensu Triska et al. 1989; Dahm et al. 1998; Hill et al. 1998; Dent et al. 2001) probably creates an $\mathrm{NO}_{3}^{-}$sink that is not addressed by the model and therefore is a potential cause of the estimated negative loading rates.

The Ipswich River and Flat Creek networks illustrate the importance of considering patterns of hydrologic connections among river channels and adjacent wetlands, riparian corridors, floodplains, and hyporheic zones (Figure 5). As flow paths from different river ecosystem components converge throughout a river network, they create important spatial areas and times of biogeochemical reactions (eg McClain et al. 2003; Hall et al. 2009) that vary in magnitude and frequency along stream courses. The potential importance of small lakes (Harrison et al. 2009), floodplains (within the Ipswich River catchment; Wollheim et al. 2008), and hyporheic zones (Thouvenot et al. 2007) on river-network nitrogen cycling has been acknowledged in some modeling studies. However, apart from reservoirs (eg Seitzinger et al. 2002; Bosch 2008), the influence of non-channel hydrogeomorphology has not been incorporated into river-network biogeochemical models, including our own (WebPanel 1). Associated simplifying assumptions mean that such models do not represent natural mechanisms of nitrogen retention or the effects of common perturbations that disrupt them. For instance, streams with well-connected, intact riparian zones/floodplains may both denitrify and store nitrogen in vegetation and sediments for long periods, reducing and delaying downstream transport. Yet agricultural and urban development in stream corridors, stream chan- 

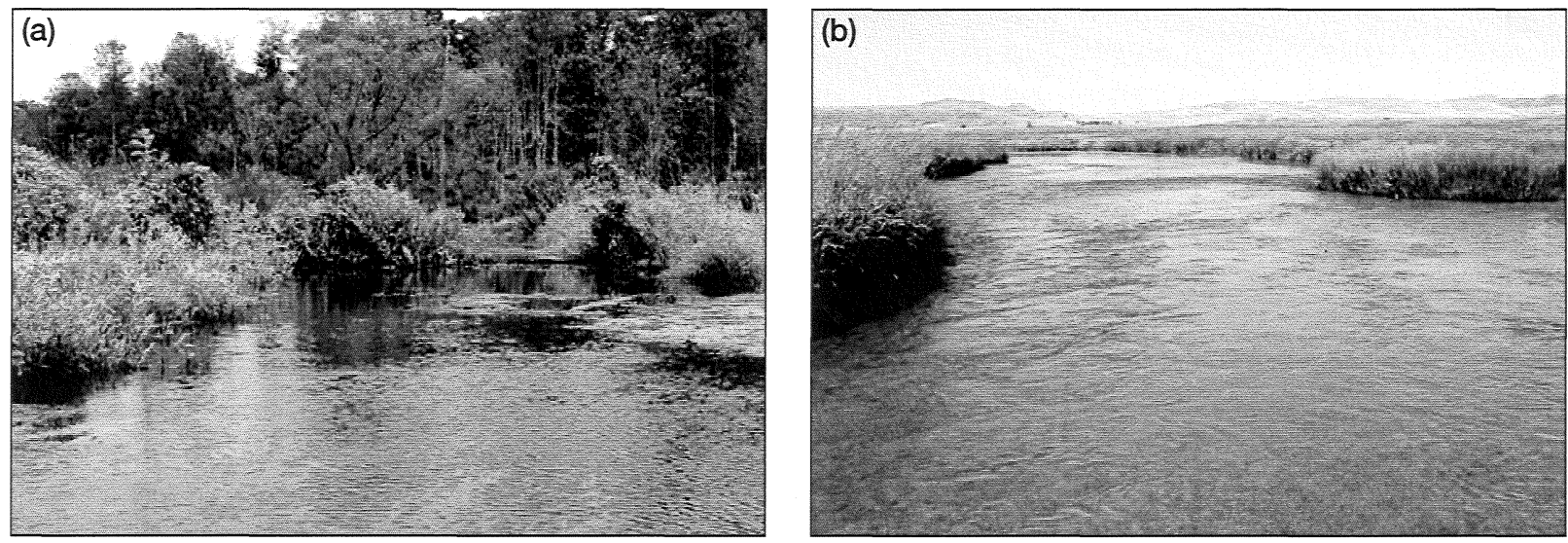

Figure 4. Examples of river hydrogeomorphology that deviate from assumptions within modeled catchments. (a) Riverine wetlands, Ipswich River, MA, catchment. (b) Spring-fed alluvial stream reach with high hyporheic exchange, Flat Creek, WY, catchment.

nel engineering, and water abstraction tend to sever hydrologic connections between channel and non-channel components of streams (Cardenas and Wilson 2004; Kondolf et al. 2006), leaving the primary location of nitrogen uptake and storage as the channelized streambed, from which carbon and nutrients are easily remobilized and transported downstream (eg Noe and Hupp 2005). These critical changes in riverine biogeochemical processing cannot be adequately investigated by models that consider only channel water and the streambed as the hydrogeomorphic basis of stream ecosystems.

\section{Nitrogen cycling and stoichiometry}

Consistent with other models of river-network nitrogen dynamics (Boyer et al. 2006; Wollheim et al. 2006), our model (WebPanel 1) assumes that denitrification is the primary nitrogen removal pathway and views the nitrogen cycle as a one-way flux of nitrogen from channel water (Figure 5). In our parameterization dataset (Mulholland et al. 2008), "direct" denitrification accounted for a wide percent of total $\mathrm{NO}_{3}^{-}$taken up by biota $(0.05-100 \%$; median 16\%). However, in most streams, $\mathrm{NO}_{3}{ }^{-}$assimilation into biomass was the largest removal flux, and assimilated nitrogen may either be stored temporarily and re-released to the water column as inorganic or organic nitrogen, or removed permanently via coupled nitrification-denitrification (eg Whalen et al. 2008) or other microbial pathways (eg reviewed by Burgin and Hamilton 2007; Figure 5). Unfortunately, the field methods (Mulholland et al. 2008) used to parameterize our model (WebPanel 1) quantify neither the subsequent cycling nor the ultimate fate of the nitrogen removed from the water column by assimilation. Furthermore, our parameterization dataset is based on denitrification measurements from headwater (1st- to 3 rd-order) streams. Measuring the role of large rivers in biogeochemical cycling (eg Tank et al. 2008) will provide improved empirical estimates of denitrification throughout river networks, allowing us to parameterize and verify models. Coupled field and modeling efforts that attempt to iteratively investigate and simulate nitrogen storage, cycling, and mass balance in streams and rivers would further accelerate understanding of spatiotemporal patterns of nitrogen cycling within, and export from, river networks.

Our model also incorporates a decline in denitrification efficiency $\left(v_{\text {ften }}\right)$ with increasing $\mathrm{NO}_{3}^{-}$concentration (Mulholland et al. 2008; Böhlke et al. 2009; WebPanel 1). The relationship is especially apparent when data from the eight catchments are combined (Mulholland et al. 2008). Yet the strength of the relationship varies markedly when considered for each of the eight catchments individually (WebTable 1), suggesting that $\mathrm{NO}_{3}^{-}$concentration was a primary driver of $v_{\text {fden }}$ in some study catchments (eg Little Tennessee River, North Carolina; $r^{2}=0.72$ ), but not in others (eg Río Piedras, Puerto Rico; $r^{2}=0.01$ ). Stoichiometric relationships between nitrogen and other elements (eg carbon, Bernhardt and Likens 2002; phosphorus, Cross et al. 2005; sulfur, Burgin and Hamilton 2008) or whole-stream respiration rates (Mulholland et al. 2008) may also drive nitrogen cycling rates. However, such dynamics cannot be addressed by river-network models that track nitrogen dynamics in isolation and use statistical representations of nitrogen uptake. More mechanistic models that consider microbial biomass and respiration, along with coupling of the nitrogen cycle to other elemental cycles (ie an ecological stoichiometry approach), would improve the heuristic value and predictive power of simulations (see also Boyer et al. 2006), yielding more robust approaches for scaling biogeochemical cycles in river networks.

\section{Temporal dynamics}

Most river-network models, including our own (WebPanel 1), simulate steady-state (eg base-flow or mean annual) hydrologic conditions (but see Wollheim et al. 2008; Böhlke et al. 2009). Steady-state hydrologic assumptions prevent simulation of dynamics that may 
(a)

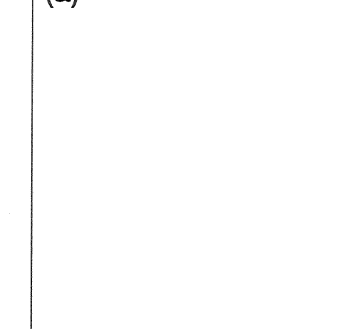

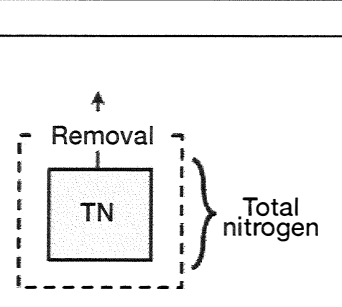

(c)

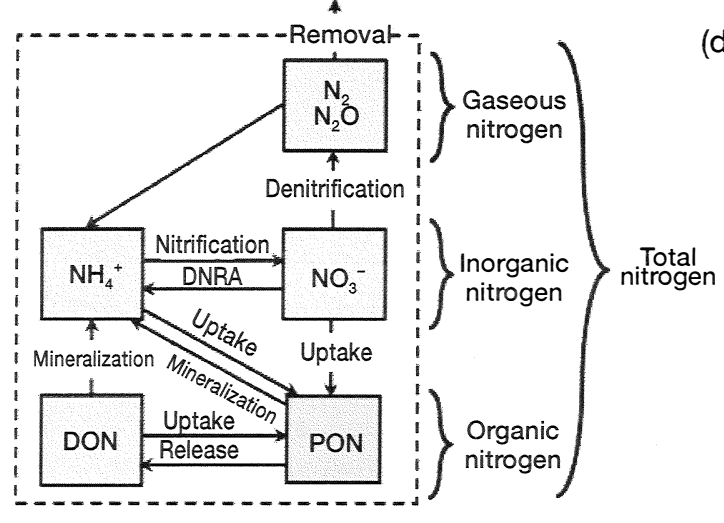

(d) (b)

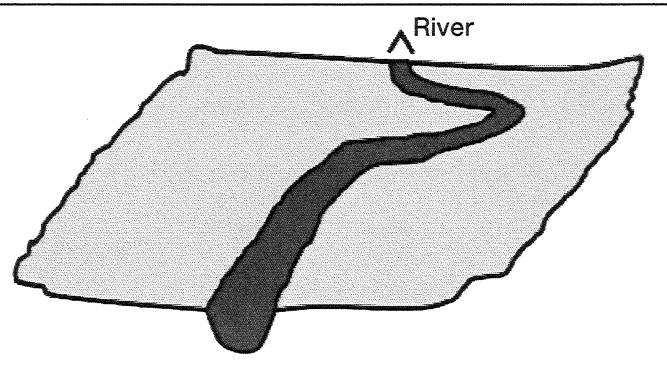

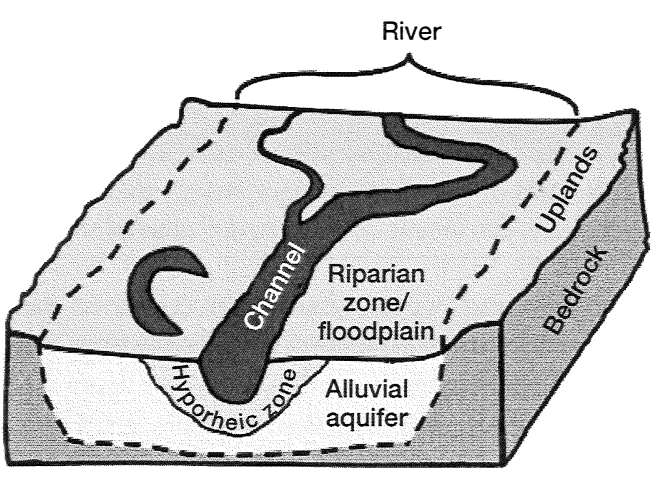

Figure 5. River-network models typically describe (a) one-way total nitrogen flux from (b) river channels. A more holistic conceptual model of nitrogen cycling in river ecosystems recognizes (c) multiple forms of nitrogen that undergo numerous transformations and (d) the role of non-channel river ecosystem components in nitrogen dynamics, including the hyporheic zone, alluvial aquifer, and floodplain/riparian complex. $\mathrm{DON}=$ dissolved organic nitrogen; $\mathrm{PON}=$ particulate organic nitrogen; $\mathrm{NH}_{4}{ }^{+}=$ammonium; $\mathrm{NO}_{3}{ }^{-}=$ nitrate; $\mathrm{N}_{2}=$ dinitrogen gas; $\mathrm{N}_{2} \mathrm{O}=$ nitrous oxide; DNRA = dissimilatory nitrate reduction to ammonium.

drive most biogeochemical processing or transport. For instance, in river channels, the fraction of catchment nitrogen exported downstream is highest during peak flows, when streambed biotic nitrogen removal efficiency is lowest (Royer et al. 2004; Alexander et al. 2009). In contrast, transient hydrologic connections with non-channel ecosystem components may buffer excess nitrogen export during high flows (Richardson et al. 2004; Hall et al. 2009). For example, transient hydrologic simulation of the Ipswich River network explored how variations in daily runoff influenced predicted denitrification patterns (Wollheim et al. 2008). The model appeared to underpredict nitrogen removal during periods of peak flow in the river network, suggesting that nitrogen may be removed by off-channel components of the stream ecosystem (eg when floodwaters spill onto floodplains or into adjacent wetlands). Indeed, storm pulses expand hydrologic connections among river ecosystem components (Stanley et al. 1997), wetting ephemeral channels and floodplains, and thereby initiating contact between different suites of solutes and activating biogeochemical processes in areas adjacent to river channels (Valett et al. 2005). Developing models that can both incorporate and scale dynamic hydrology across river networks presents a formidable challenge, yet is a critical necessity for improving models of rivernetwork biogeochemistry.

\section{The way forward}

Four fundamental and widely applied assumptions caused our model to fail in six out of eight catchments. Our model: (1) assumes that catchment topography drives water and nitrogen accumulation in river networks; (2) represents streams as channels, ignoring the floodplain, wetland, riparian, and hyporheic components of streams; (3) simulates nitrogen uptake in isolation rather than nitrogen cycling in the context of ecological stoichiometry; and (4) assumes a steady-state discharge regime. We believe, therefore, that overcoming these assumptions will extend the applicability and predictive accuracy of river-network biogeochemical models across a range of catchments. On the basis of these findings, we recommend several specific strategies to help extend and improve current modeling approaches.

\section{Integration of river-network and catchment ecohydrologic models}

Hydrologic and physical properties of catchments strongly control nitrogen delivery to rivers, but river-network models do not normally simulate hydrologic nitrogen delivery to rivers. Ecohydrologic models (reviewed by Boyer et al. 2006; Kulkarni et al. 2008) simulate hydrologically explicit hillslope nitrogen dynamics across catchments, even predicting 


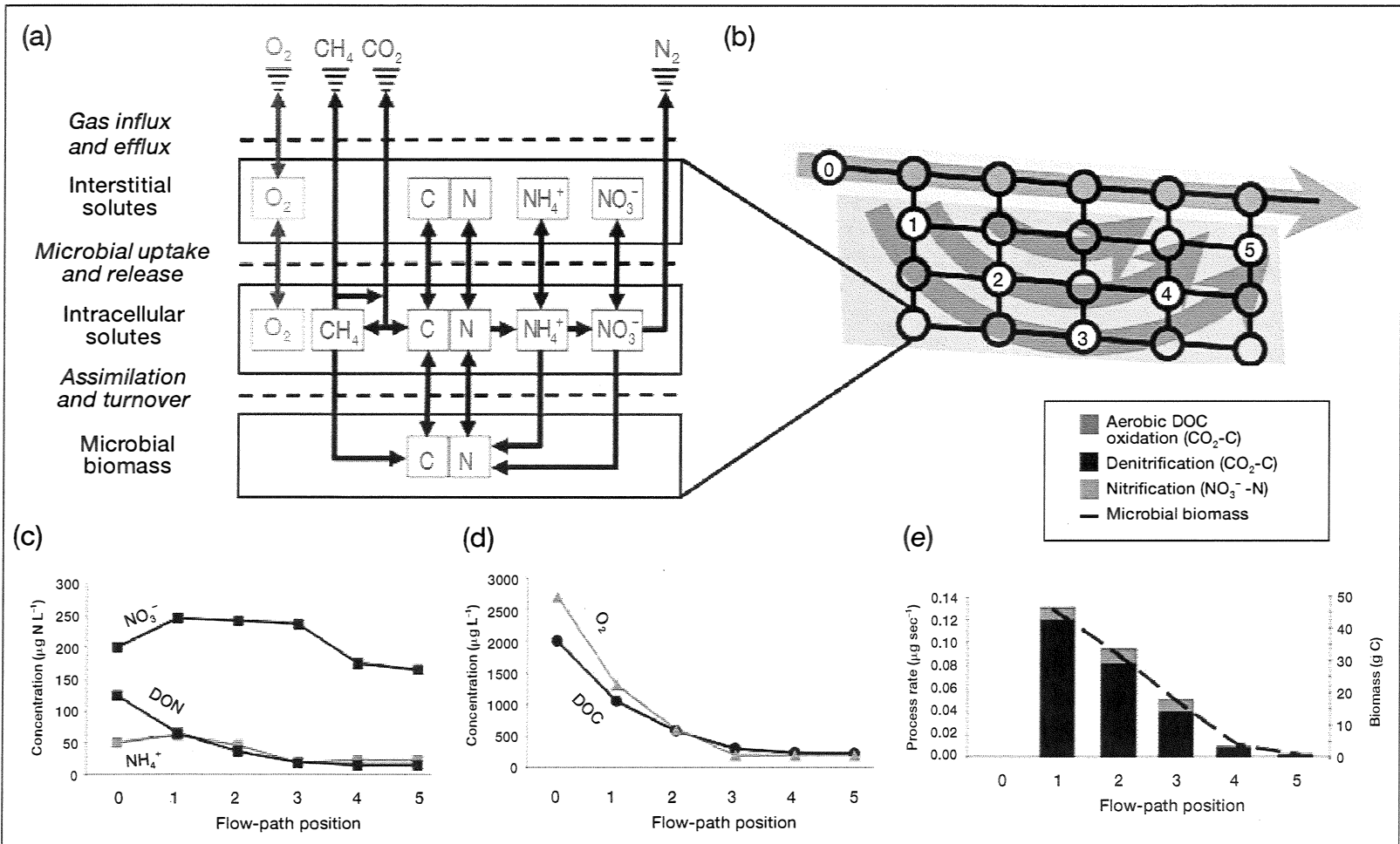

Figure 6. Simulation of multi-element biogeochemical cycles along a hyporheic flow path. (a) Schematic of a prototype biogeochemical model (AM Helton et al. unpublished) that simulates microbial uptake and utilization and/or production of dissolved organic matter, oxygen, nitrate, ammonium, and methane. The model operates by assuming that microbial assemblages will use the suite of metabolic pathways that will maximize microbial growth, as co-limited by the availability of carbon, nitrogen, and oxygen as electron donors/acceptors and the stoichiometric ratio of carbon and nitrogen required for building biomass. (b) Simulated hydrologic flow paths in a simple two-dimensional implementation of a mechanistic model of surface water flow and hyporheic exchange (hydrology model described by Poole et al. 2006). We combined the two models to simulate hydrologic solute flux and (c) concentrations of different nitrogen forms ( $D O N=$ dissolved organic nitrogen), (d) dissolved oxygen and dissolved organic carbon (DOC), and (e) microbial activity and biomass along an idealized hyporheic flow path (numbered circles in [b]).

observed patterns and timing of water and nutrient delivery to streams (Band et al. 2001). Such catchment ecohydrologic models could be linked to river-network models, to provide spatially explicit and temporally dynamic estimates of water and nutrient delivery to streams - an important first step for understanding biogeochemical dynamics at the terrestrial-aquatic interface.

Catchment ecohydrologic models, however, still typically rely on topography as the primary determinant of catchment water and solute routing. Yet existing modeling techniques that accurately represent the hydrologic dynamics of human-dominated catchments generally require detailed and difficult-to-obtain information, such as patterns of tile drainage in agricultural lands or sewer system maps in urbanized settings (eg Hsu et al. 2000; Northcott et al. 2002). Thus, improved simulation of river-network biogeochemistry may also arise from the development of new, less data-intensive techniques that could quantify water and nutrient routing dynamics in urban and agricultural catchments without requiring detailed maps and descriptions of sewer or drain systems.

\section{Modeling stoichiometric controls on biogeochemical cycles}

River-network nitrogen models tend to simulate one-way removal of nitrogen. Such an approach has been quite successful when used to quantify annual nitrogen budgets of large catchments (Alexander et al. 2002). However, the nitrogen cycle is driven by multiple nitrogen pools and fluxes (Figure 5) and its relationships with other elemental cycles (eg carbon and oxygen). A more mechanistic representation of nitrogen dynamics might therefore help to explain complex patterns of biogeochemical dynamics within river networks, and improve forecasts of biogeochemical responses to land-use or climate-change perturbations.

Biogeochemical cycling depends on the changing availability of various electron donors and acceptors, given the thermodynamically constrained metabolism of microorganisms (Hedin et al. 1998; Fisher et al. 2004). Thus, stoichiometric constraints on microbial metabolism link multiple elemental cycles in complex yet predictable ways. Indeed, microbial ecology models can predict carbon and nitrogen 


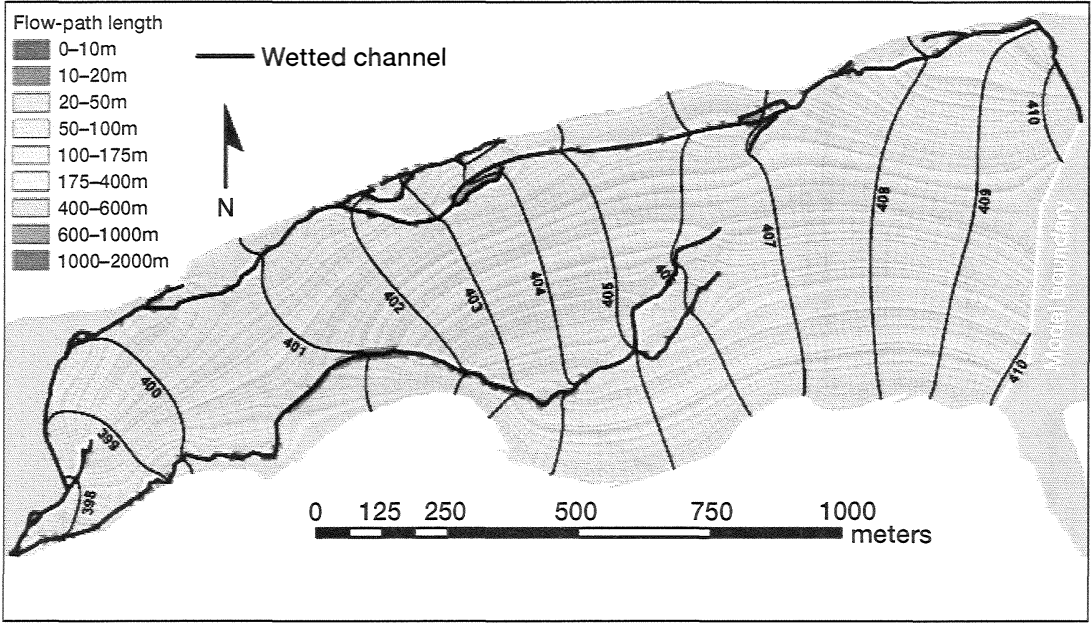

Figure 7. Simulated spatial juxtaposition of individual flow paths within a floodplain aquifer (modified from Poole et al. 2008; ${ }^{\circ} 2008$ John Wiley and Sons Ltd. Reproduced by permission). Heavy black lines show the center of active channels. Colors along the channels denote subsurface (hyporheic) flow-path length at each point of flow-path discharge back to the channel. Absence of color along the channel denotes points of hyporheic recharge from the channel. Black contours represent simulated water table elevations $(m)$. Simulated aquifer flow paths are indicated by gray background striations.

models yield realistic patterns of nitrogen (Figure 6c), oxygen, and organic carbon (Figure $6 \mathrm{~d}$ ), as well as microbial biomass and respiration (Figure 6e), along hyporheic flow paths. By using the hydrologic model to simulate floodplain surface and subsurface flow paths (Figure 7), we will be able to develop realistic, multi-element models of whole floodplain biogeochemistry.

Still, direct application of a spatially explicit, flow-path-centric approach (Figure 6) to an entire river network is not feasible because of the intensive data needs for parameterization and verification, along with the computational requirements needed to execute such a model. We believe, however, that river-network models incorporating both hydrogeomorphic and stoichiometric controls on biogeochemistry could be developed

uptake, assimilation, and loss, based on the assumption that the aggregate metabolic activity of the microbial assemblage present will respond to oxygen, carbon, and nitrogen availability in such a way as to maximize overall growth (eg Vallino et al. 1996; Figure 6a). Such an approach, based on the first principles of thermodynamics (ie free energy yield from metabolic pathways), provides an avenue for addressing shifting drivers of the nitrogen cycle across systems. This comprehensive biogeochemical approach also highlights important contemporary research challenges, including: quantifying the fraction of nitrogen forms that make up the total nitrogen pool, understanding the interaction of nitrogen with other elements, and understanding the role and shifting frequency of alternate nitrogen removal pathways (eg coupled nitrification-denitrification).

\section{Using river hydrogeomorphology to scale biogeochemistry}

Although river-network models typically incorporate general trends of channel geometry and in-channel hydrology (eg WebPanel 1), they often disregard geomorphic variation in, and hydrologic connections between, the channel, riparian zone/floodplain, and hyporheic zone (Figure 5), even though such connections are key to understanding river biogeochemical dynamics (McClain et al. 2003; Groffman et al. 2009). Thus, to simulate river-network biogeochemistry, a reliable approach for scaling biogeochemistry to flow paths is needed. For example, we have begun to integrate the aforementioned stoichiometric biogeochemical model (Figure 6a) into a spatially explicit and temporally dynamic model of hydrologic flow paths (Poole et al. 2006; Figure 6b). Initial results suggest the combined within the next decade. One promising approach would pair stream biogeochemical models with contemporary efforts by hydrologists to use theoretical approaches (Cardenas 2008) and simulation modeling (Deng and Jung 2009) as a means of scaling up the net effect of localized, off-channel hydrologic processes, such as hyporheic water exchange. Thus, the next generation of models might emerge from coupling network-scale hydrologic residence-time distributions with a robust understanding of flow-path biogeochemistry. Maturation of emerging geospatial technologies, such as LIDAR (Light Detection and Ranging; Jones et al. 2007, 2008) and SRTM (Shuttle Radar Topography Mission; Farr et al. 2007), will ultimately improve the practicality of quantifying hydrogeomorphic variation (sensu Wörman et al. 2006) across river networks to parameterize associated models of rivernetwork hydrologic residence time distributions.

\section{Conclusions}

We recommend an admittedly ambitious roadmap for developing the next generation of river-network models. Rather than attempting to implement all of our recommendations simultaneously, which may lead to overly cumbersome models that are difficult to parameterize and run, incremental improvements coupled with experimentation is more likely to succeed. We have outlined three specific paths to improve river-network biogeochemistry models, which can be accomplished incrementally and independently of one another. First, we propose using ecohydrologic models to improve estimated spatiotemporal patterns of water and nutrient delivery to river networks. Human alterations will complicate these patterns, and 
methods to scale their effects - for example, effects of storm-sewer and tile drainage systems on nutrient and water routing to whole river networks - will be essential, particularly as human impacts become increasingly prevalent. Second, we propose incorporating multiple elemental cycles and ecological stoichiometry into river-network models. Our initial approach (Figure 6) integrates first principles of thermodynamics (ie free energy yield from metabolic pathways) with governing equations for surface and groundwater fluxes, and should therefore be widely applicable. Maturation of such an approach, however, will require increased collaboration between empirical, simulation, remote sensing, geographical, and computer sciences to create, model, and understand datasets describing biogeochemical fluxes across an array of environmental conditions and scales. Finally, we propose integrating biogeochemical models and floodplain-scale hydrology models (eg Figure 7), which will provide important insights into the biogeochemical dynamics of multiple interacting flow paths within fluvial landscapes. The challenge will be to develop methods to scale these integrated biogeochemistry-hydrology models to whole river networks.

Developing models that can accurately represent hydrogeomorphic and biogeochemical dynamics across river networks will require the melding of concepts and approaches from both terrestrial and aquatic biogeochemical modeling, as well as hydrologic modeling and remote-sensing sciences. Application of these models will yield insights into the river-network biogeochemistry necessary for understanding carbon and nutrient cycling across a variety of fluvial landscapes and among diverse biomes. As anthropogenic activities, such as land-use conversion and fossil-fuel production, push ecosystems toward unprecedented states, a holistic and mechanistic approach to biogeochemical modeling of rivers will provide a valuable tool for forecasting the responses of biogeochemical cycles across river networks worldwide.

\section{Acknowledgements}

This research was supported by NSF (DEB-0111410). Additional support was provided by NSF for BJP and SMT (DEB-0614301), for WMW (OCE-9726921 and DEB-0614282), for WHM and JDP (DEB-0620919), for SKH (DEB-0423627), and by the Gordon and Betty Moore Foundation for AMH, GCP, ESB, and JAS, and by an EPA Star Fellowship for AMH. EPA has not officially endorsed this publication and the views expressed herein may not reflect the views of the EPA. We thank C Bennett for programming assistance and the Rosemond Lab Group at the University of Georgia for helpful comments on earlier versions of this manuscript.

\section{References}

Alexander RB, Böhlke JK, Boyer EW, et al. 2009. Dynamic modeling of nitrogen losses in river networks unravels the coupled effects of hydrological and biogeochemical processes. Biogeochemistry 93: 91-116.
Alexander RB, Johnes PJ, Boyer EW, et al. 2002. A comparison of models for estimating the riverine export of nitrogen from large watersheds. Biogeochemistry 57: 295-339.

Alexander RB, Smith RA, and Schwarz GE. 2000. Effect of stream channel size on the delivery of nitrogen to the Gulf of Mexico. Nature 403: 758-61.

Band LE, Tague CL, Groffman P, et al. 2001. Forest ecosystem processes at the watershed scale: hydrological and ecological controls of nitrogen export. Hydrol Process 15: 2013-28.

Bernhardt ES and Likens GE. 2002. Dissolved organic carbon enrichment alters nitrogen dynamics in a forest stream. Ecology 83: 1689-1700.

Böhlke JK, Antweiler RC, Harvey JW, et al. 2009. Multi-scale measurements and modeling of denitrification in streams with varying flow and nitrate concentration in the upper Mississippi River basin, USA. Biogeochemistry 93: 117-41.

Bosch NS. 2008. The influence of impoundments on riverine nutrient transport: an evaluation using the Soil and Water Assessment Tool. J Hydrol 355: 131-37.

Boyer EW, Alexander RB, Parton WJ, et al. 2006. Modeling denitrification in terrestrial and aquatic ecosystems at regional scales. Ecol Appl 16: 2123-42.

Burgin AJ and Hamilton SK. 2007. Have we overemphasized the role of denitrification in aquatic ecosystems? A review of nitrate removal pathways. Front Ecol Environ 5: 89-96.

Burgin AJ and Hamilton SK. 2008. $\mathrm{NO}_{3}^{-}$driven $\mathrm{SO}_{4}{ }^{2-}$ production in freshwater ecosystems: implications for $\mathrm{N}$ and $\mathrm{S}$ cycling. Ecosystems 11: 908-22.

Cardenas MB. 2008. Surface water-groundwater interface geomorphology leads to scaling of residence times. Geophys Res Lett 35; doi:10.1029/2008GL033753.

Cardenas MB and Wilson JL. 2004. Impact of heterogeneity, bed forms, and stream curvature on subchannel hyporheic exchange. Water Resour Res 40; doi:10.1029/2004WR003008.

Cross WF, Benstead JP, Frost PC, et al. 2005. Ecological stoichiometry in freshwater benthic systems: recent progress and perspectives. Freshwater Biol 50: 1895-1912.

Dahm CN, Grimm NB, Marmonier P, et al. 1998. Nutrient dynamics at the interface between surface waters and groundwaters. Freshwater Biol 40: 427-51.

Darracq A and Destouni G. 2005. In-stream nitrogen attenuation: model-aggregation effects and implications for coastal nitrogen impacts. Environ Sci Technol 39: 3716-22.

Deng ZQ and Jung HS. 2009. Variable residence time-based model for solute transport in streams. Water Resour Res 45; doi:10.1029/2008WR007000.

Dent CL, Grimm NB, and Fisher SG. 2001. Multiscale effects of surface-subsurface exchange on stream water nutrient concentrations. J N Am Benthol Soc 20: 162-81.

Diaz RJ and Rosenberg R. 2008. Spreading dead zones and consequences for marine ecosystems. Science 321: 926-29.

Farr TG, Rosen PA, Caro E, et al. 2007. The shuttle radar topography mission. Rev Geophys 45; doi:10.1029/2005RG000183.

Fisher SG, Sponseller RA, and Heffernan JB. 2004. Horizons in stream biogeochemistry: flowpaths to progress. Ecology 85: 2369-79.

Groffman PM, Butterbach-Bahl K, Fulweiler RW, et al. 2009. Challenges to incorporating spatially and temporally explicit phenomena (hotspots and hot moments) in denitrification models. Biogeochemistry 93: 49-77.

Hall RO, Baker MA, Arp CD, and Koch BJ. 2009. Hydrologic control of nitrogen removal, storage, and export in a mountain stream. Limnol Oceanogr 54: 2128-42.

Harrison JA, Maranger RJ, Alexander RB, et al. 2009. The regional and global significance of nitrogen removal in lakes and reservoirs. Biogeochemistry 93: 143-57.

Hedin LO, von Fischer JC, Ostrom NE, et al. 1998. Thermodynamic constraints on nitrogen transformations and other biogeochemical processes at soil-stream interfaces. Ecology 79: 684-703. 
Hill AR, Labadia CF, and Sanmugadas K. 1998. Hyporheic zone hydrology and nitrogen dynamics in relation to the streambed topography of a N-rich stream. Biogeochemistry 42: 285-310.

Hsu MH, Chen SH, and Chang TJ. 2000. Inundation simulation for urban drainage basin with storm sewer system. J Hydrol 234: 21-37.

Jones AF, Brewer PA, Johnstone E, et al. 2007. High-resolution interpretative geomorphological mapping of river valley environments using airborne LiDAR data. Earth Surf Proc Land 32: 1574-92.

Jones KL, Poole GC, O'Daniel SJ, et al. 2008. Surface hydrology of low-relief landscapes: assessing surface water flow impedance using LIDAR derived digital elevation models. Remote Sens Environ 112: 4148-58.

Kondolf GM, Boulton AJ, O'Daniel S, et al. 2006. Process-based ecological river restoration: visualizing three-dimensional connectivity and dynamic vectors to recover lost linkages. Ecol Soc 11: 5 .

Kulkarni MV, Groffman PM, and Yavitt JB. 2008. Solving the global nitrogen problem: it's a gas! Front Ecol Environ 6: 199-206.

Leopold LB and Maddock T. 1953. The hydraulic geometry of streams and some physiographic implications. US Geological Survey Professional Paper 252. Washington, DC: United States Government Printing Office.

Lindgren GA and Destouni G. 2004. Nitrogen loss rates in streams: scale-dependence and up-scaling methodology. Geophys Res Lett 31; doi:10.1029/2004GL019996.

McClain ME, Boyer EW, Dent CL, et al. 2003. Biogeochemical hot spots and hot moments at the interface of terrestrial and aquatic ecosystems. Ecosystems 6: 301-12.

Mulholland PJ, Helton AM, Poole GC, et al. 2008. Stream denitrification across biomes and its response to anthropogenic nitrate loading. Nature 452: 202-46.

Noe GB and Hupp CR. 2005. Carbon, nitrogen, and phosphorus accumulation in floodplains of Atlantic Coastal Plain rivers, USA. Ecol Appl 15: 1178-90.

Northcott WJ, Cooke RA, Walker SE, et al. 2002. Modeling flow on a tile-drained watershed using a GIS-integrated DRAINMOD. T ASAE 45: 1405-13.

Poole GC, Stanford JA, Running SW, et al. 2006. Multiscale geomorphic drivers of groundwater flow paths: subsurface hydrologic dynamics and hyporheic habitat diversity. J N Am Benthol Soc 25: 288-303.

Poole GC, O'Daniel SJ, Jones KL, et al. 2008. Hydrologic spiralling: the role of multiple interactive flow paths in stream ecosystems. River Res Appl 24: 1018-31.

Richardson WB, Strauss EA, Bartsch LA, et al. 2004. Denitrification in the Upper Mississippi River: rates, controls, and contribution to nitrate flux. Can J Fish Aquat Sci 61: 1102-12.

Royer TV, Tank JL, and David MB. 2004. Transport and fate of nitrate in headwater agricultural streams in Illinois. J Environ Qual 33: 1296-304.

Seitzinger SP, Harrison JA, Böhlke JK, et al. 2006. Denitrification across landscapes and waterscapes: a synthesis. Ecol Appl 16: 2064-90.

Seitzinger SP, Styles RV, Boyer EW, et al. 2002. Nitrogen retention in rivers: model development and application to watersheds in the northeastern USA. Biogeochemistry 57: 199-237.

Stanley EH, Fisher SG, and Grimm NB. 1997. Ecosystem expansion and contraction in streams. BioScience 47: 427-35.
Tank JL, Rosi-Marshall EJ, Baker MA, and Hall RO. 2008. Are rivers just big streams? A pulse method to quantify nitrogen demand in a large river. Ecology 89: 2935-45.

Thouvenot M, Billen G, and Garnier J. 2007. Modelling nutrient exchange at the sediment-water interface of river systems. J Hydrol 341: 55-78.

Triska FJ, Kennedy VC, Avanzino RJ, et al. 1989. Retention and transport of nutrients in a third-order stream in northwestern California: hyporheic processes. Ecology 70: 1893-1905.

USDA (US Department of Agriculture). 2002. Census of agriculture. National Agricultural Statistics Service. Washington, DC: USDA. www.nass.usda.gov/Census_of_Agriculture/index.asp. Viewed 13 Dec 2008

Valett HM, Baker MA, Morrice JA, et al. 2005. Biogeochemical and metabolic responses to the flood pulse in a semiarid floodplain. Ecology 86: 220-34.

Vallino JJ, Hopkinson CS, and Hobbie JE. 1996. Modeling bacterial utilization of dissolved organic matter: optimization replaces monod growth kinetics. Limnol Oceanogr 41: 1591-1609.

Whalen SC, Alperin MJ, Nie Y, et al. 2008. Denitrification in the mainstem Neuse River and tributaries, USA. Fund Appl Limnol 171: 249-61.

Wollheim WM, Peterson BJ, Thomas SM, et al. 2008. Dynamics of $\mathrm{N}$ removal over annual time periods in a suburban river network. J Geophys Res - Biogeo 113: G03038.

Wollheim WM, Vorosmarty CJ, Peterson BJ, et al. 2006. Relationship between river size and nutrient removal. Geophys Res Lett 33; doi:10.1029/2006GL025845.

Wörman A, Packman AI, Marklund L, et al. 2006. Exact threedimensional spectral solution to surface-groundwater interactions with arbitrary surface topography. Geophys Res Lett 33; doi:10.1029/2006GL025747.

Zarriello PJ and Ries KG. 2000. A precipitation-runoff model for the analysis of the effects of water withdrawals on stream flow, Ipswich River basin, Massachusetts. Denver, CO: US Geological Survey Information Services. USGS Water-Resources Investigation Report 00-4029.

${ }^{4}$ Ecosystem Center, Marine Biological Laboratory, Woods Hole, MA; ${ }^{5}$ Environmental Sciences Division, Oak Ridge National Laboratory, Oak Ridge, TN; 'Biology Department, Duke University, Durham, NC; ${ }^{7}$ Flathead Lake Biological Station, University of Montana, Polson, MT; ${ }^{8}$ Department of Biological Sciences, University of Notre Dame, Notre Dame, IN; ${ }^{9}$ Department of Fisheries and Wildlife, Oregon State University, Corvallis, OR; ${ }^{10}$ Chesapeake Biological Laboratory, University of Maryland Center for Environmental Sciences, Solomons, MD; " Division of Biology, Kansas State University, Manhattan, KS; ${ }^{12}$ Department of Zoology and Physiology, University of Wyoming, Laramie, WY; ${ }^{13}$ Kellogg Biological Station, Michigan State University, Hickory Comers, MI; ${ }^{14}$ Pacific. NW Research Station, US Forest Service, Corvallis, OR; ${ }^{15}$ Department of Natural Resources and the Environment, University of New Hampshire, Durham, NH; ${ }^{16}$ Department of Biological Sciences, Virginia Polytechnic Institute and State University, Blacksburg, VA; ${ }^{17}$ Department of Biology, University of New Mexico, Albuquerque, NM 